\title{
Is Arm-span an accurate measure of stature? A cross sectional study in North Indian population
}

\author{
Pinki Rai', Ashima Das ${ }^{2}$, Surendra Kumar ${ }^{3}$, Ritika Girdhar ${ }^{4}$, Paras Kumar ${ }^{5}$, Nishtha Saini ${ }^{6}$ \\ ${ }^{1}$ Demonstrator, ${ }^{2}$ Associate Professor, Department of Anatomy, SHKM Government Medical College, Nuh, India, ${ }^{3}$ Senior \\ Resident, Department of Orthopaedics, SHKM Government Medical College, Nuh, India, ${ }^{4}$ Senior Resident, Department \\ of Psychiatry, SHKM Government Medical College, Nuh, India, ${ }^{5}$ Post Graduate student, Department of Anatomy, SGT \\ University, Gurugram, India, ${ }^{6}$ Professor, Department of Opthalmology, SHKM Government Medical College, Nuh, India
}

Background: The estimation of inter-relationship between various body parameters and stature has been an important tool in anthropometric measurements. It is found to be of great importance in such cases where direct measurement of stature is not possible. A wide variety of parameters are used for estimation of stature including arm spam, hand length, foot length, demi span, knee height, sitting position etc. In this study arm span is used for stature estimation. Aims and Objective: To find the accuracy of arm-span in predicting standing height of both males and females in studied population. Materials and Methods: The study involved 600 participants (300 males and 300 females). The data for study collected from Rajasthan by means of community visits. The standing height and arm-span were measured for each individual and analyzed. Correlation coefficient and regression equation was generated. Results: A positive correlation was found to exist between the arm-span and stature. The correlation coefficient $r$ was found to be 0.9. In the studied population, the arm span was found to be a strong predictor of Stature. Conclusion: It can be concluded that arm-span can be used in estimation of the height of both males and females. Arm span is reliable tool for obtaining the approximate stature of an individual. It can be used for the purpose of medico-legal cases too.

Keywords: Body height; Measurement; Prediction; Standing height; Stature; Arm span
Access this article online

\section{Website:}

http://nepjol.info/index.php/AJMS

DOI: 10.3126/ajms.v12i7.35768

E-ISSN: 2091-0576

P-ISSN: 2467-9100

Copyright (c) 2021 Asian Journal of Medical Sciences

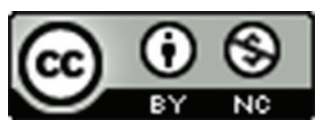

This work is licensed under a Creative Commons Attribution-NonCommercial 4.0 International License.

\section{INTRODUCTION}

Stature is definitely an important feature of an individual. It is found to vary in various ethnic groups. ${ }^{1}$ In the field of research height of person is used on various grounds. It can be as simple as identification of race or ethnic group or for therapeutic purposes like evaluation of nutritional state, calculation of dose of drugs to be administered or it can also be used for complicated scenarios like in cases of mass destruction for the identification purposes. ${ }^{2,3}$ There are many modalities used for estimation of stature i.e. using arm spam, hand length, foot length, demi span, knee height, sitting position etc., but methods involving long bones are sought to be as more reliable. ${ }^{4,5}$ Although personnel identification can be accurately done using DNA sampling and fingerprints but in certain conditions the soft tissues are not available like rotten or burnt bodies, natural disasters and buried remains. ${ }^{6}$ In such circumstances estimation of height using long bones and arm span is of great importance. Other than this stature estimation in individuals with growth and developmental abnormality like scoliosis, skeletal dysplasia or in cases of height loss due to amputation or surgical procedures is also beneficial using arm span. The reliability of this method has been documented. ${ }^{5,7}$ Nowadays, stature is widely used in clinical settings for estimation of body surface area, vital capacity, basal metabolic rate (BMR), renal clearance and body mass index (BMI) of patients. ${ }^{1}$

The aim of present study was to final if there was any correlation exists in the study population. And also to 
find arm span could be used as a tool for prediction of stature.

\section{MATERIALS AND METHODS}

This cross sectional study was carried out in Rajasthan State of Northern India. The participants were randomly selected from the target population and 300 males and 300 females (total 600) willingly participated in the study. The protocol of study was approved by National Institute of medical sciences, Jaipur. The duration of study was two years i.e. 2013-2015. Parameters measured were stature (standing height) and arm-span using the steel tape. Purpose of study was explained to the participants and verbal consent was taken.

\section{Inclusion criteria}

Only healthy individual in age of 26 to 55 year free from any skeletal abnormality or developmental defects were included in the study. The included individuals were ensured with ability to stand straight and who were willing to participate.

\section{Exclusion criteria}

Any physical deformity or syndrome. Individuals with previous musculoskeletal injuries or inability to stand erect or amputation were excluded from the study. ${ }^{8}$

\section{Steps of measurement}

Stature: Individual was asked to stand straight bare feet on the ground against the wall with feet together and arms hanging by side of body. Mark was placed on the wall at the level of highest point (vertex). The height was measured from the mark to ground using steel tape (Figure 1).

Arm span: Individual was asked to stand erect against the wall and arms were outstretched at 90 degrees with palms facing forwards. The arm span was measured from tip of middle finger if one hand to the tip of middle finger of other hand using steel measuring tape (Figure 2).

All the measurements were taken twice and the mean was taken to the nearest $0.1 \mathrm{~cm}$ for further analysis. Dummy tables were prepared on paper first later excel sheet was prepared for the recorded data. ${ }^{9}$

\section{Statistical analysis}

Descriptive statistics describing mean and standard deviation, Skewness and Kurtosis method to test the normality of data, and after considering its results; t paired $t$-test were applied to analyze the data. Significance level was considered less than .05 $(P<.05)$. Analysis was done using

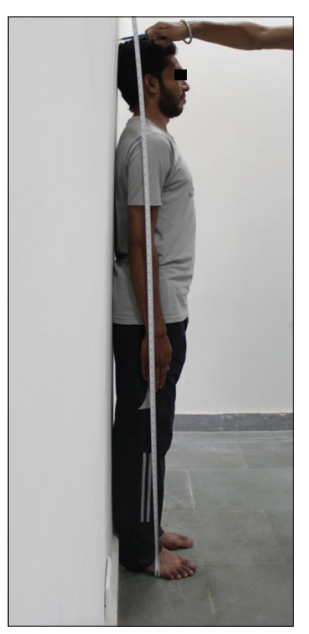

Figure 1: Measurement of stature

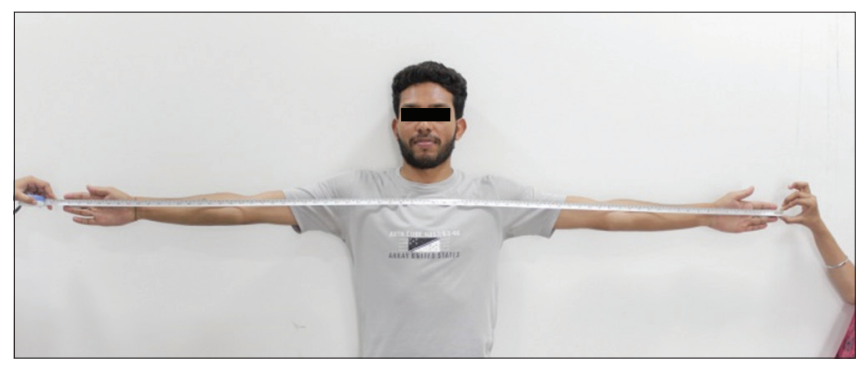

Figure 2: Measurement of Arm-span

SPSS 22. Correlations were obtained among the parameters. Linear regression analysis was performed to evaluate the prediction of stature using regression equation i.e. $\mathrm{Y}=\mathrm{a}+$ bX. Stature $=$ value of constant + regression coefficient $X$ Arm span $Y=a+b X$, where $Y=$ Stature (in centimeter), $\mathrm{a}=$ constant, $\mathrm{b}=$ regression coefficient and $\mathrm{X}=$ Arm span (in centimeter). [10] The data was tabulated and results were plotted as graphs.

\section{RESULTS}

The analyzed data on 600 subjects was represented in tables and graphs. The tables and graphs given in this section are self-explanatory.

Arm span and stature data distribution was checked by applying normality test (Table 1). Normality test could be analyzed by skewness and kurtosis.

According to skewness and kurtosis, if a value which falls between -1 to 1 and -3 to 3 respectively, the data is said to be having the normal distribution. Our study parameters Arm span and stature data was having normal distribution.

The data of Table 2 shows the gender wise description of study participants. 
The descriptive stat for the total population is shown in Table 3.

A positive correlation was found in parameters of both males and females (Figures 3 and 4). The correlation coefficient value is shown in Table 4.

We observed highly positive correlation in entire population as well as gender (Figure 5). $87 \%$ of height among total population was significantly measured by arm span using regression equation (Table 5).

In gender, 61\% and 70\% arm span height significantly measured by stature respectively in male and female.

1 unit increase in Arm Span corresponds to 0.87 unit of increase in stature. The high adjusted $\mathrm{R}$ squared tells us that our model successfully goes with arm span in predicting Stature (Table 6).

On top of that, our b coefficients are all statistically significant and make perfect intuitive sense.

Stature $=0.868 *$ AS +16.773, where, AS $=$ Arm Span $)$

\section{DISCUSSION}

The stature estimation has been active area of interest among researchers due to its wide applicability. ${ }^{11}$ Forensic experts and archeologists deal with human remains and try to determine and reconstruct the identity, stature, build and

\begin{tabular}{|c|c|c|c|c|c|}
\hline \multicolumn{6}{|c|}{ Descriptive Statistics } \\
\hline & \multirow{2}{*}{$\begin{array}{c}\mathbf{N} \\
\text { Statistic }\end{array}$} & \multicolumn{2}{|c|}{ Skewness } & \multicolumn{2}{|c|}{ Kurtosis } \\
\hline & & Statistic & $\begin{array}{l}\text { Std. } \\
\text { Error }\end{array}$ & Statistic & $\begin{array}{l}\text { Std. } \\
\text { Error }\end{array}$ \\
\hline $\begin{array}{l}\text { Arm } \\
\text { Span }\end{array}$ & 600 & -0.010 & 0.100 & -0.964 & 0.199 \\
\hline Stature & 600 & 0.171 & 0.100 & -1.123 & 0.199 \\
\hline
\end{tabular}

race of the fragments found. The present study has been carried out on living humans and regression equation has been derived to know the success of arm span model for stature estimation.

A total of six hundred participants were part of this study with equal proportion of males and females, so the groups were comparable like that of study conducted by Sharma S et al. (2016) where males and females were 200 each. ${ }^{8}$ The age of study participants varied from 25 year to 55 year, the reason for choosing beginning age as 25 for this study was that the ossification of all long bones

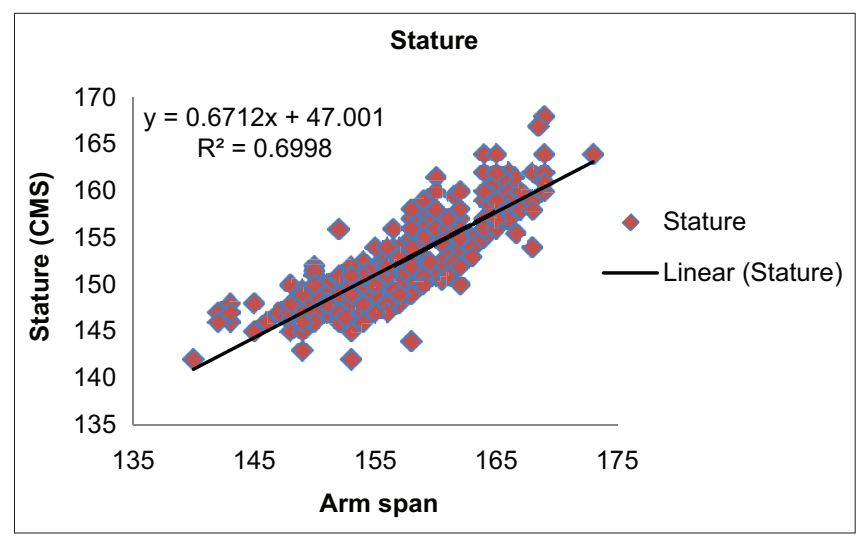

Figure 3: Correlation and Regression analysis on total females $(\mathrm{N}=300)$

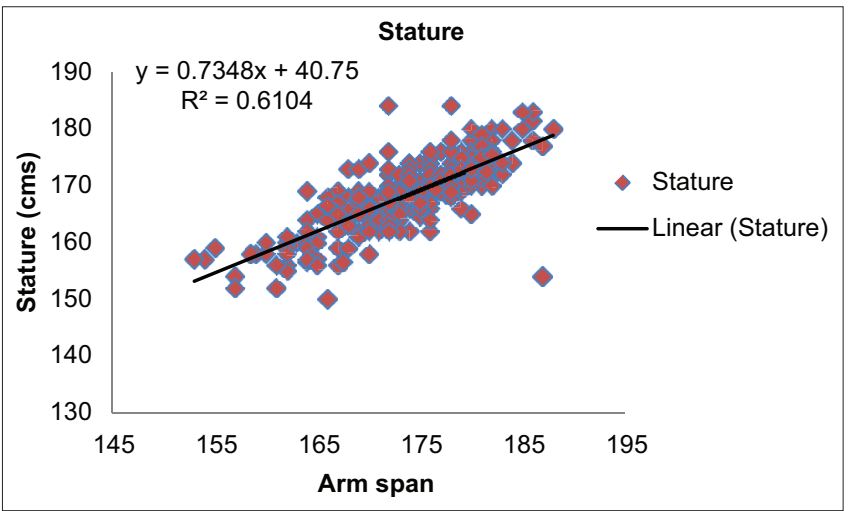

Figure 4: Correlation and Regression analysis on total males $(\mathrm{N}=300)$

Table 2: Descriptive statistics for males and females of study population

\begin{tabular}{|c|c|c|c|c|c|}
\hline Parameter & $\mathbf{N}$ & Minimum & Maximum & Mean & Standard Deviation \\
\hline Stature Male & 300 & 150 & 184 & 168.41 & 6.05 \\
\hline Stature Female & 300 & 142 & 168 & 152.39 & 4.83 \\
\hline Arm span Male & 300 & 153 & 188 & 173.73 & 6.43 \\
\hline Arm Span Female & 300 & 140 & 173 & 157.02 & 6.02 \\
\hline
\end{tabular}

Table 3: Descriptive statistics for total study population

\begin{tabular}{|c|c|c|c|c|c|}
\hline Parameter & $\mathbf{N}$ & Minimum & Maximum & Mean & Standard Deviation \\
\hline Stature & 600 & 142 & 184 & 160.40 & 9.71 \\
\hline Arm span & 600 & 140 & 188 & 165.37 & 10.42 \\
\hline
\end{tabular}


is complete by that age. Although, various researchers has chosen different age ranges i.e. 18-25year, 18-24, 20-49, 18-20, 8-99, 19-32 as per their study requirements. ${ }^{8,9,12-14}$ Despite of being a same race, we humans have a variety of shapes, sizes and features. These have been found to be unique in populations of different ethnic groups and

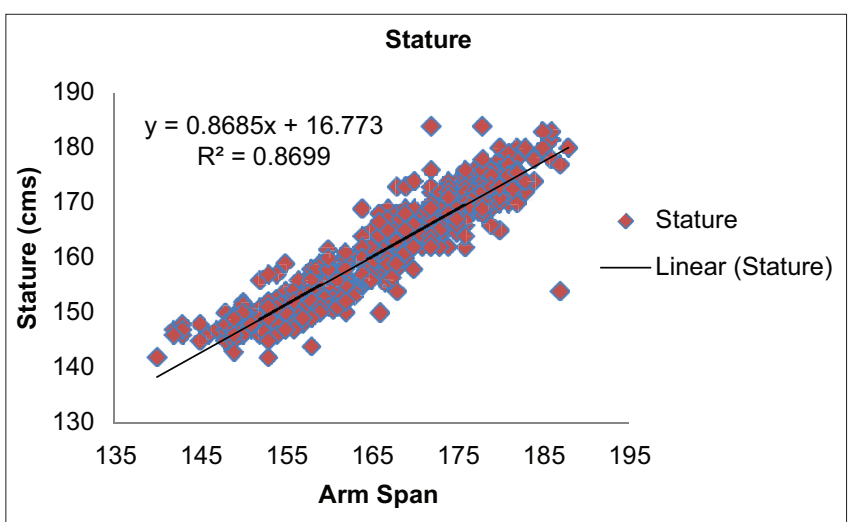

Figure 5: Correlation and Regression analysis on total population $(\mathrm{N}=600)$

\begin{tabular}{|c|c|c|}
\hline Subject & Correlation coefficient $(r)$ & Significant $P$ value \\
\hline Total & 0.933 & $<0.0001$ \\
\hline Male & 0.781 & $<0.0001$ \\
\hline Female & 0.837 & $<0.0001$ \\
\hline
\end{tabular}

Table 5: Regression Coefficient of arm span and stature

\begin{tabular}{lcc}
\hline Subject & $\mathbf{R}^{\mathbf{2}}$ & Significant $\mathbf{P}$ value \\
\hline Total & 0.870 & $<0.0001$ \\
Male & 0.610 & $<0.0001$ \\
Female & 0.700 & $<0.0001$ \\
\hline
\end{tabular}

geographical regions., 15, 16 These differences give power to anthropological studies for knowing the uniqueness among different populations. In the present study, the average stature of males was significantly higher than that of females. However the similar pattern was observed by other researchers too. 1,2,5,7,10,12 Although it has been proved that male skeleton is larger than females (Nieves JW et al., 2005).

In the present study, the average Arm span like that of stature was found to be greater in males than in females, which was in congruence with the studies conducted by Shah 2013; Alam 2016; Chawla 2013 and Rai 2015. Due to significant differences in parameters of males and females, different regression equations are required for estimating the stature of both sexes. ${ }^{9}$ The correlation coefficient $\mathrm{R}$ for arm span and stature was observed as 0.78 for males and 0.87 for females. The similar results have been reported by previous studies too. ${ }^{9,17-19}$ In total population of 600 participants, the correlation coefficient was even higher i.e. 0.93 ( $\mathrm{p}$-value $<0.0001$ )

In the present study, the mean arm span was higher than mean stature both in males and females as well as in combined population. But this is not always true for all populations (Table 7).

In Bosnian and Herzegovinian population, arm span was slightly lesser in females than average stature which is contrary to results of our study. ${ }^{7,20,21}$ Although most studies have supported the results of present study but differences make the population unique among others. The extent of correct measurement of stature by arm span using regression equation was also high in present study.

\section{Table 6: Unstandardized and Standardized Regression Coefficients}

\begin{tabular}{|c|c|c|c|c|c|c|c|c|}
\hline \multicolumn{9}{|c|}{ Coefficients $^{a}$} \\
\hline \multirow{2}{*}{\multicolumn{2}{|c|}{ Model }} & \multicolumn{2}{|c|}{$\begin{array}{l}\text { Unstandardized } \\
\text { Coefficients }\end{array}$} & \multirow{2}{*}{$\begin{array}{c}\begin{array}{c}\text { Standardized } \\
\text { Coefficients }\end{array} \\
\text { Beta }\end{array}$} & \multirow[t]{2}{*}{$t$} & \multirow[t]{2}{*}{$\begin{array}{l}\text { Sig. Lower } \\
\text { Bound }\end{array}$} & \multicolumn{2}{|c|}{$\begin{array}{c}95.0 \% \text { Confidence I } \\
\text { nterval for B }\end{array}$} \\
\hline & & B & Std. Error & & & & Lower Bound & Upper Bound \\
\hline \multirow[t]{2}{*}{1} & (Constant) & 16.773 & 2.275 & & 7.371 & $<0.0001$ & 12.305 & 21.242 \\
\hline & Arm Span & 0.868 & 0.014 & 0.933 & 63.243 & $<0.0001$ & 0.842 & 0.895 \\
\hline
\end{tabular}

\section{Table 7: Comparison with previous studies}

\begin{tabular}{|c|c|c|c|c|c|c|}
\hline \multirow[t]{2}{*}{ Sr No } & \multirow[t]{2}{*}{ Researcher } & \multirow[t]{2}{*}{ Year } & \multicolumn{2}{|c|}{ Avg. Stature (Mean+SD) } & \multicolumn{2}{|c|}{ Avg. Arm span (Mean+SD) } \\
\hline & & & Males & Females & Males & Females \\
\hline 1. & Goon et al & 2011 & $167.4(6.6)$ & $160.2(5.2)$ & $173.2(9.1)$ & $164.2(5.9)$ \\
\hline 2. & Popovic et al & 2015 & $183.87 \pm 7.11$ & $171.82 \pm 6.56$ & $184.50 \pm 8.27$ & $169.85 \pm 8.01$ \\
\hline 3. & Sharma et al & 2016 & $168.13 \pm 5.89$ & $156.00 \pm 5.61$ & $175.03 \pm 7.01$ & $159.01 \pm 6.32$ \\
\hline 4. & Arifi et al & 2017 & $179.52 \pm 5.96$ & $165.72 \pm 4.93$ & $181.20 \pm 7.02$ & $165.60 \pm 5.87$ \\
\hline 5. & Present Study & 2020 & $168.41 \pm 6.04$ & $152.38 \pm 4.8$ & $173.72 \pm 6.43$ & $157.07 \pm 6.01$ \\
\hline
\end{tabular}




\section{CONCLUSION}

A statistically significant result for estimation of stature in gender as well as the whole population is suggestive of using Arm span as a tool to estimate the height. For a particular population the averages of stature and arm span should be known before applying the regression equation.

\section{ACKNOWLEDGEMENT}

I am highly grateful to Dr. Upendra Kumar Gupta (Professor and Head, Department of Anatomy, NIMS Medical College, Jaipur) for his supervision and guidance throughout the study. I also appreciate the cooperation of participants and other helping staff.

\section{REFERENCES}

1. Brown JK, Feng JY and Knapp TR. Is self-reported height or arm span a more accurate alternative measure of height. Clin Nurs Res. 2002; 11(4):417-432.

https://doi.org/10.1177/105477302237454

2. Chawla M , Rajkumar, Tomar S and Ashoka A. Relationship between arm span and height in adult males of north Indian Punjabi population. J Evol Med Dental Sci. 2013; 2(4); 332-339.

3. Devi KA, Islam M and Chinglensana L. Measurement of stature from arm-span-an anthropometric study on chakma tribal tripuri females. J Evol Med Dental Sci. 2014; 3(04): 876-881.

4. Rai P, Das A, Agrawal AK and Arora D. Physical Anthropometry in Estimation of Stature: A Systematic Review. Int J Cur Res Rev. 2020; 12(24): 75-79.

http://dx.doi.org/10.31782/IJCRR.2020.122409

5. Shah RK, Nirvan AB, Patel JP, Patel B and Kanani S. Estimating Stature From Arm Span Measurement in Gujarat Region. GCSMC J Med Sci. 2013; 2(2):13 30-32.

6. Jasuja OP and Singh G. Estimation of stature from hand and phalange length. JIAFM. 2004 26(3): 100-106.

7. Popovic S, Bjelica D and Doina GT. Body Height and Its Estimation Utilizing Arm Span Measurements in Bosnian and Herzegovinian Adults. Monten J Sports Sci Med. 2015; 4 (1): 29-36.

8. Sharma S, Jain SK and Sharma N. Use of Arm Span as Proxy Indicator of Stature- An Anthropometric Study in Western U.P. Ann Int Med Den Res. 2016; 2(5):AT10-AT14.

9. Supare MS, Bagul AS, Pandit SV and Jadhav JS. Estimation of Stature from Arm Span in Medical Students of Maharashtra,
India. Ann Med Heal Sci Res. 2015; 5(3): 218-221.

10. Alam MT, Singh S, Rai R and Shaheen S. Correlation between Stature and Arm Span: A Prospective Regional Study in Eastern Uttar Pradesh. Ann Int Med Den Res. 2016; 2(3):56-60.

11. Rai P, Gupta UK, Ashima and Chawla A. Correlation between arm span and stature in different age groups-An anthropometric study in population of Rajasthan. Int J Biomed Res. 2015; 6:794-799. https://doi.org/10.7439/ijbr.v6i10.2591.

12. Goon TD, Toriola AL, Ibrahim D, Musa and Akusu S. The relationship between arm span and stature in Nigerian adults. Kinesiology. 2011; 43(1): 38-43.

13. Arifi F, Bjelica D, Sermaxhaj S, Gardasevic J, Kezunovic M and Popovic S. Stature and its estimation utilizing arm span measurements in Kosovan adults: National survey. Int J Morphol. 2017; 35(3):1161-1167.

14. Philip Q, Capderou A, Mazicioglu MM, Aggarwal AN, Popovic S, Tayie F, et al. All-age relationship between arm span and height in different ethnic groups. Eur Resp J. 2014; 44. 905-912.

15. Popović $S$, Bjelica D, Molnar S, Jakšić D and Akpinar. Body Height and Its Estimation Utilizing Arm Span Measurements in Serbian Adults. Int J Morphol. 2013 31(1), 271-279.

16. Nieves JW, Formica C, Ruffing J, Zion M, Garrett P, Lindsay R, et al. Males Have Larger Skeletal Size and Bone Mass than Females, Despite Comparable Body Size. J Bone Miner Res. 2005; 20:529-535. https://doi.org/10.1359/JBMR.041005

17. Golshan M, Crapo RO, Amra B, Jensen RI and Golshan R. Arm span as an independent predictor of pulmonary function parameters: validation and reference values. Respirology. 2007; 12 (3): 361-366.

18. Rai P, Saxena AK, Mehrotra N and Aneja PS. Morphometric analysis of frontal sinus dimensions using digital radiographs. Int J Res Pharm Sci. 2020; 11 (4): 6023-6027. https://doi.org/10.26452/ijrps.v11i4.3267

19. Rhiu I and Kim W. Estimation of stature from finger and phalange lengths in a Korean adolescent. Journal of Physiological Anthropology. 2019; 38:13.

https://doi.org/10.1186/s40101-019-0206-1

20. Sharma A, Barman B, Das GC, Saikia H and Momin AD. Correlation between the armspan and the standing height among males and females of the Khasi tribal population of Meghalaya state of NorthEastern India. J Family Med Prim Care. 2020; 9:6125-6129.

https://doi.org/10.4103/jfmpc.jfmpc_1350_20

21. Gerver WJM, Gkourogianni A, Dauberd A, Nilsson A and Wit JM. Arm Span and Its Relation to Height in a 2- to 17-YearOld Reference Population and Heterozygous Carriers of ACAN Variants. Horm Res Paediatr. 2020; 93:164-172. https://doi.org/10.1159/000509867

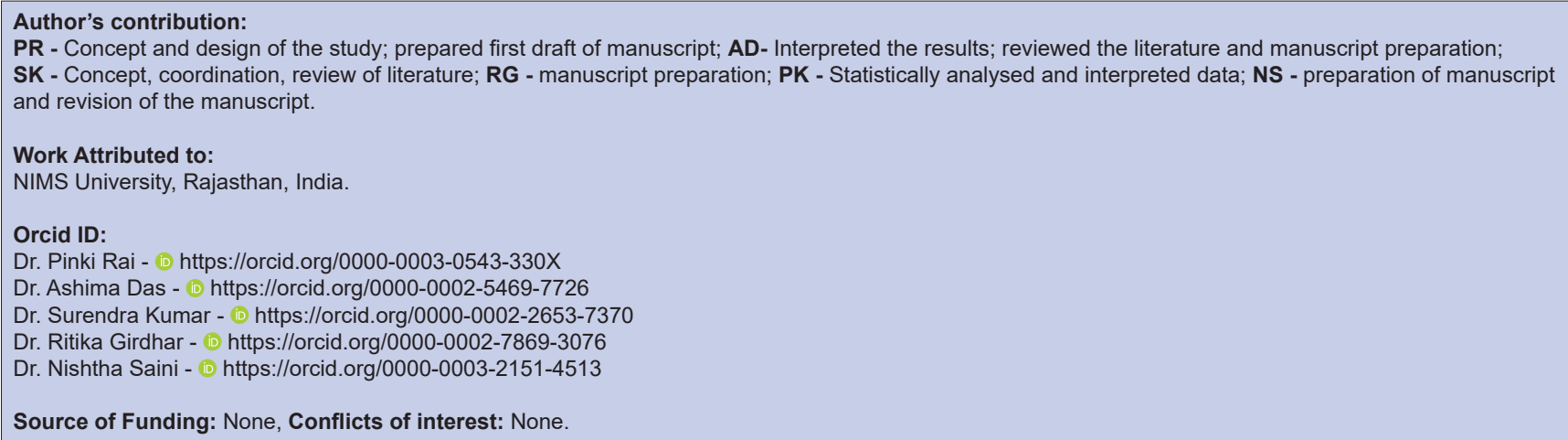

